Article

\title{
Designing the Future
}

\section{Friso de Zeeuw ${ }^{1}$, Agnes Franzen ${ }^{1}{ }^{*}$, Kristel Aalbers ${ }^{1}$, Anke van Hal ${ }^{1,2}$ and Birgit Dulski ${ }^{2}$}

1 Faculty of Architecture, TU Delft, P.O. Box 5043, 2600 GA Delft, The Netherlands; E-Mails: W.C.T.F.deZeeuw @ tudelft.nl (F.Z.); K.P.M.Aalbers@ tudelft.nl (K.A.); J.D.M.vanHal@tudelft.nl (A.H.)

2 Center for Sustainability, Nyenrode Business University, P.O. Box 13-620 AC, The Netherlands; E-Mails: B.Dulski@nyenrode.nl (B.D.); a.vanhal@nyenrode.nl (A.H.)

* Author to whom correspondence should be addressed; E-Mail: a.j.franzen@tudelft.nl; Tel.: +31-625007356.

Received: 26 January 2010; in revised form: 16 March 2010 / Accepted: 17 March 2010 / Published: 1 April 2010

\begin{abstract}
The Netherlands has a tradition in public spatial planning and design. In the past 20 years, we have seen an increasing role for the market in this field, and more recently, growing attention for sustainability. Sustainability has become an economic factor. Not only at the building level, but also on the level of large-scale area development projects. More and more local governments have high ambitions for sustainable development. Increasingly, during project development, buildings are developed on a sustainable basis. Most of the time, the focus in this approach is on energy. However, sustainability also comprises social aspects. Energy measures have a direct relation to an economic factor such as investment costs, and payback time can be calculated. The economic aspects of social sustainability are more complex. Therefore, for all sustainability development projects, especially in large-scale projects planned over a longer period, it is necessary to make presumptions, which are less reliable as the planning period is extended. For future larger-scale developments, experience in the Netherlands points to two design approaches: 'backcasting', or using a growth model (or a combination of these two). The power of design is the ability to imagine possible scenarios for the future. The layer approach helps to integrate sustainability into public spatial planning. And more specifically, Urban Design Management (UDM) supports an integrative and collaborative approach also on the operational level of a project in which public and market partners work together. This article outlines how design, based on these approaches, can contribute to sustainable development based on the 'new playing field', where spatial
\end{abstract}


problems should be solved in networks. Dutch projects in Almere (Benoordenhout) and Rijswijk are used to illustrate this approach.

Keywords: sustainable urban area development; strategy; urban design management

\section{Introduction}

The Netherlands has a long tradition in the field of spatial planning, spatial policies and 'designing futures'. In the past decades, the playing field has changed, as private developers became dominant players in spatial planning. Within this changed playing field, the role of design also changed. Whereas in the 1980s many former civil servants started their own companies carrying out public and increasingly also private commissions, in the 1990s we witnessed an emerging sector of real estate developers in concept development. The craft of design broadened from the public to the private sphere. In (democratic) processes a design became an important strategic instrument. This article outlines how a design approach can contribute to sustainable development based on this 'new playing field', in which context spatial problems should be solved in networks on both the strategic and the operational level.

The second part of the 20th century, in particular in Europe, can be characterized as a government-focused century. In the Netherlands, after the post-war period of reconstruction, in which the focus was on quantitative housing, with the urban renewal in the 1970s and early 1980s the quality of housing became more important. This was related to inner-city renewal of predominantly outdated pre-war housing stock. In those years, retaining and reinforcing the economic appeal of city centers in particular was also a major development challenge for Dutch government bodies. These developments of the 1970s and 1980s continued into the 1990s. In addition to paying attention to employment, there was increasing attention for retaining middle-income and higher-income groups in the cities. Since the 1970s, this category of residents turned away from inner cities by leaving to districts outside of the city. An important policy choice at the start of the 1990s was to build a compact city, referred to as a VINEX location (a site designated by the government for future urban development) named after the relating policy document.

As urban challenges changed, the nature of public housing as a 'development tool' of the government also changed. Under Heerma, the State Secretary for Housing, government corporations for housing were privatized in the late 1980s. It was the period of 'withdrawing government'. Decentralization was in place, in the context of which central government instructed municipalities to develop VINEX locations in cooperation with commercial organizations.

It was a period in which government policy shifted from development control planning to development planning. At a local level, this was translated into urban area development; an approach in which context government, commercial organizations and civil society involved in an urban area, integrated the process of planning and the implementation of spatial projects [1,2]. Dutch policy in this context is focused on the regulation of the market and market stimulation. In this context public law is used to influence spatial planning and not, as we see in other countries, private law [3]. 
For a long time, sustainability was mostly associated with environmental issues such as air pollution and reducing mobility. Most VINEX locations are developed within this perspective, the production of dwellings still being a dominant driving force for development. Only the VINEX location Nieuwland in Amersfoort distinguished itself by a fully integrated view on sustainability. In the VINEX location Leidsche Rijn in Utrecht, a small part called 'Kersentuin' is developed by citizens with social and technical sustainability as preconditions.

In line with the recently produced Dutch structural concept 'Randstad 2040', produced by the national government, the focus in the next few years will be on strong cities and strong landscapes. As a result of the economical crisis, housing in itself will become a less dominant driver. The expected main new driving forces will be infrastructure, water, landscape, energy and socio-economic investments. Area development is about connecting the content of a specific spatial, socio-economic question to processes of participation and decision-making by the actors involved. This has always been the case, but due to globalism, the growth of prosperity and an ongoing process of democracy, questions have become more independent of scale and the process has become more complex. The playing field has changed. In the 1960s, the government was dominant, in the 1970s and 1980s, in addition to city renewal, the government passed the power on to its citizens, and in the 1990s private developers became dominant players, as can be seen in a film made for the Architectural Biennale 2009 about ways in which to create cities [4]. The Dutch city of Rotterdam was the main example provided in this film.

This paper is structured as follows: Section 2 focuses on the new playing field. Section 3 describes the added value of a new sustainable approach (the layer approach) and Section 4 deals with Urban Design Management (UDM) as a method. The last part of this article links all the former information to the description of two approaches for sustainable development, illustrated here by the cases of Almere and Rijswijk, two Dutch projects in the Randstad. Both these cases involved the knowledge of, and were developed in co-production by, the authors of this article.

\section{New Playing Field}

In our contemporary network society, the government, the business sector and civil society are increasingly faced with long-standing controversies over complex societal problems. These problems are characterized by a high degree of adverse opinions. This first manifests itself in the fact that the parties involved disagree not only about the solution but even about the nature of the problem. Research and academic expertise are sought upon to establish clarity. Flyvbjerg [5] emphasizes the importance of interdisciplinary thinking and the interaction between a theoretical approach and practical knowledge. It is difficult to incorporate urban area development and science into one analytical frame. Different perspectives and theoretical backgrounds need to be combined. In terms of practical knowledge, a feature of these issues is that they cut across the traditional domains of organizations and across the traditional boundaries between the public and private sector. Government bodies, the business sector and civil society are unable to tackle these issues by themselves. The complexity of these issues gives rise to areas of interaction: the actors are forced to operate in the context of strategic games and networks that are new to them, and in which their standard operating procedures are no longer adequate [6]. 
The following definition of urban area development illustrates this complexity in regard to planning, design and real estate development: 'urban area development is the art of connecting functions, disciplines, parties, interests and flows of funds, with an eye to (re)developing an area' [1,2].

In the early 1990s, commercial organizations such as real estate developers, major builders and-in a later stage - various housing corporations, started manifesting themselves more actively in the drafting and planning processes as well as in the land development of projects. The changes in this playing field between government and the market have taken on a structural nature. One of the persistent operational issues involved when a government and the market cooperate in an area project is the question: where should the government have a steering role, and where not? Due to the current effects of the economic crisis, this question is becoming more pressing. In the 1990s, extensive steering was self-evident, particularly in extension areas of large municipalities. Inner-city projects with a mixed program and smaller municipalities showed more variation. The above changes in the 1990s resulted in a shift in planning towards market parties. Today, commercial organizations are becoming more involved in the early stages of processes when ideas and plans are formed. Although this may not be new to many Anglo-Saxon countries, for the Netherlands with its strong government-driven development tradition in the 20th century, this means a shift in planning.

In addition to these commercial organizations, there are many other organizations, companies and citizens willing to increasingly invest in spatial development projects. Within this new playing field, it is often unclear what tasks the government should actually have, and what is better left to commercial organizations and other parties. Precisely what this management entails turns out to be open to many interpretations. For this reason, it can be helpful for public and private actors to make explicit what this management role may be. And what type of law is needed in this context. At the government level, this forces thinking about public interests requiring government steering or assurance. For that matter, public interests are never neutral and they cannot be determined objectively; they always contain a political element and they may differ in time, place and type of area of responsibility [2].

Looking at the subject of sustainability, knowledge and technologies on sustainability are growing, but the mindset of the actors involved is conservative on this subject. Disseminating knowledge of the added value of sustainability should for this reason have priority [7]. The underlying fact is the value pluralism of the different actors involved. This raises the question of which strategies can be legitimate and effective for planning and design in this new playing field, without denying the politicization in the Greek sense, that is, as the universalization of particular demands that aim at 'more' than negotiation of interests. [8].

\section{The Added Value of a New Sustainable Approach}

Not only a new playing field has emerged, but also in regards to planning and design we see a shift during this period, for example from blueprint thinking to more dynamic and sustainable forms of planning. In 1986, the landscape office HNS won a regional design competition (EO Wijers) for the region of Arnhem with 'plan Ooievaar' (Stork plan). This plan can be seen as the shift from rational blueprint planning and design to more dynamic flexible planning and design. The core of the plan was to separate high and low dynamic functions. Years later, the principles of this idea resulted in the 'layer approach' (lagenbenadering), which became essential in thinking about sustainability in spatial 
planning. In 2003, the City Region of Haaglanden published the document MIRUP (Milieu in Ruimtelijke Plannen; the environment in spatial planning), which focused on the integration of environmental issues in spatial planning and was supposed to become a tool for environmental and spatial planners at the local level [9]. This was only one initiative among a range of initiatives within the field of sustainability, but of special interest here because the layer approach was given a central place in the 'Nota Ruimte' (urban space policy document) of the central government, published in 2005. Moreover, we see this approach as an analytical framework that can support sustainable development on larger-scale area developments. In the layer approach, the spatial area is split into three different layers. The first and most stable layer is the underground. Changes in this layer take more than 100 years. The second layer comprises the networks of infrastructure and water. The energy system can also be classified in this layer. This layer has a time span of 25 to 100 years. The third layer is the use of the space by different functions such as for living, working and recreation. Different authors later added the social layer, or the layer of the users. Since the introduction of this approach, there has been growing knowledge on the added value of sustainable development. Green surroundings have proven to have positive effects on the health of people, water like canals and lakes have had a measureable effect on house prices, and it has now been proven that opting for a larger-scale system can save energy costs.

Sustainability has become an economic factor in spatial planning in terms of cost reduction regarding energy, climate maintenance, health and recycling material. Urban (city) development in the past years had a strong focus on generating future growth and attracting investment capital and consumers. The search for competitive redevelopment was a leading objective in the new urban policy in an attempt to reassert the position of cities in the consolidation of the global economy. Physical reconstruction and economic recovery tend to go hand-in-hand [7]. Due to the economic crisis and the increasing importance of sustainability on the political agenda, we might see a shift to sustainability in this so-called post-politics condition. Not in the sense of governing Beyond-the-State, but in the social and political acceptance of neoliberal cosmopolitan globalization. Both on the level of politics and on the more operational level we see a movement towards a more 'environmental' and 'social' approach to urban area development. In this perspective, economic factors still remain important in urban development projects, but are more inclined to be linked to a sustainable agenda.

Both for market and public organizations the end user will become more important, as a customer and as a citizen with a commitment to the building environment. The challenge for all involved parties for the coming years is to acquire more insight into effective strategies on the area level, which connects spatial qualities with sustainable requirements on the economic, social (citizens and customers) and environmental level. Only by such an integral approach, an increase of economical and societal value in area development is possible. In this context, the layer approach should be seen not only as a governmental instrument to obtain more insight into the planning commission, but also as an instrument for political debate and to address the actors involved with respect to the realization of sustainable development. 


\section{Urban Design Management as a Method}

Due to climate and energy problems, sustainability and durability feature high on the political agenda and constitute an essential part of the political en governmental practice. This practice is no longer strongly focused on governmental leadership (government setting the rules), but on operating in strategic networks and increasingly on merging interests [10]. Often this leads to conflicts of interest. Such conflicts can be instrumental (process), based on different interests (content) or different values (communication). In this paper, we state that Design Thinking, as in Urban Design Management (UDM), can be an effective method for dealing with these conflicts at the operational level of an urban area project. Design is defined as a creative process that leads to the visualization of a possible future or strategy, an idea, a more juridical plan (regulation) or a technical plan for implementation. The challenge for designers in UDM is to leave room in the urban designs they produce for differing opinions and debate at the level of governmental politics. This means no blueprint designs, but a more conceptual approach. An example of this is the spatial concept for Rijswijk described below. During a UDM approach, general agreement should be reached on this concept. At a later stage, different elaborations are possible within this conceptual approach. A weak point of the method is that it tends to become a closed process, which leaves room for disagreement but only between the actors involved. Another weak point can be its focus on integration. Not everything can be integrated; a certain amount of focus is needed. As defined earlier, urban area development is a method for the (re)development of an (urban) area. From the perspective of the new playing field, it involves disciplines such as real estate development, planning and design. The theory of UDM is based on the Mutual Gains Approach (MGA) [10] as well as the integration of different disciplines, like infrastructure, housing, economy or for example archaeology. The method focuses on the realization of area development by merging interests, and includes mediation among a range of stakeholders with their own interests involved in the production of the built environment. At the operational level, we should consider public and private commissioners, but also the different policy and technical disciplines involved such as water, housing, economy, civil engineering and energy from different organizations. Mediation can encourage a joint search for mutually beneficial outcomes, or in UDM terms so-called Integrative Development. Integrative Development links stakeholders at various scales and in multiple contexts and aims to create more sustainable solutions by increasing stakeholder satisfaction with the process and content of urban development towards a level of integrated quality [11]. Sustainability can be a guiding element in this ambition.

How does it work? Design is used to visualize different interests and ambitions. In an iterative research and design process, different possible solutions are tested. The integration of different interests resulting from a creative design process is a key element in this approach. In this way, UDM as an instrument can help to create a shared ambition based on positive energy and commitment. However, not everything can be solved by way of consensus. What counts here is that 'we agree to disagree'. Ambition from this perspective is not the same as an accumulation of requests. Not wanting to or not being able to choose a feasible ambition creates stagnation and frustration. Politics and public debate play an important role in this perspective, both in a positive and in a negative way (frustration of technical good solutions). 
Cooperation in a shared ambition presumes shared policy-making and shared decision-making too, which is not always easy for government organizations that are used to set the rules. It involves more participation from residents and social organizations. For governments to really provide room for private investments, a delegating, interactive and facilitating management style is of importance. This means that a government focuses much more on (conceptual) frameworks within which others can work out a policy. In other words: governments can also support the policies of others. A good example of this on a national level is the Spatial Planning Policy Document. In this document, the central government focuses on several national spatial core tasks and creates a spatial framework. If a government body chooses to adopt a facilitating or delegating style at a specific moment or in a specific area, there will be more room for private entrepreneurship and various forms of risk spreading.

UDM can support the creation of a spatial framework by interaction between the strategic (politics) and the operational level. Within this resulting framework other democratic approaches can work as associative initiatives of groups of people, or even a more revolutionary approach in which a group of citizens convince the local government or a local entrepreneur of the public or economic benefit of a specific sustainable approach. And as stated earlier, to organize these examples in foreign countries shows the added value of using, not only public, but also private law. A necessary condition for this is flexibility in the framework, which should be combined with a sustainable approach in terms of choices and investments.

\section{Two Approaches to Sustainable Development by Co-Production}

UDM makes it possible to visualize possible futures, including the (political) choices that need to be made. Since not all disagreements can be solved, working towards a sustainable urban area development means making (political) choices at different levels of scale. In terms of sustainability, the focus in the past years was on the scale of the building level and small neighbourhoods of 500 dwellings. For large-scale developments in the near future, a combination of the layer approach and UDM looks promising. The layer can be used as an analytical framework for urban designers in relation to questions of sustainability and adaptability. Adaptability is a process of constantly changing environmental conditions and stress factors. The inherent uncertainties regarding our changing climate, as well as the effects of interventions on the urban space, make a high level of adaptability desirable [12]. In this context, we will introduce two approaches for adaptive sustainable design; 'backcasting' and 'growth model' design.

\subsection{Backcasting and Growth Model Design}

Backcasting means designing a sustainable end situation for a larger-scale area. In solving problems of virtually any kind, the way to achieve the best outcome is to imagine what the ideal solution would be and than work backwards to where you are today. This ensures that you do not erect imaginary obstacles before you even know what the ideal is [13]. This 'future design' is used to make system choices at the network level; infrastructure, energy and water. This approach can be used for the scale of 1,500 or 2,000 dwellings. It concerns mostly one-off major investments such as geothermic, public transport and water systems. A problem is that at this moment for larger area developments it takes at 
least 10 to 15 years before these investment pay themselves back. Consequently, for financial reasons, most of the time other small-scale options are opted for as a start. In the end, these do not invariably lead to the most sustainable approach. An alternative is growth model design. In this approach it is not an ultimate end situation for 1,500 or 2,000 dwellings that is leading, but possible solutions on a scale of 150-500 dwellings. Thus, this approach is based on smaller steps; small-scale developments with a more incremental decision-making process. This small-scale development creates flexibility for future choices. The basic idea is to make every small step sustainable, based on the latest (technical) knowledge. A disadvantage can be that a more effective sustainable strategy that requires a larger scale is excluded, which in the end is not only less sustainable but also more expensive in terms of investment.

In relation to the layer approach, more research is necessary to formulate financial strategies that can support investments in the first and second layer. As for the first layer (the underground), long-term investments are inevitable. Backcasting can be a good strategy for this layer. For the second layer (the network layer), a choice between one of the two strategies is possible, or a combination. This layer should be adaptable in the sense that it can facilitate the flexibility of the third layer. The third layer (the occupational layer), obliges the most adaptability. The fourth (user) layer must be kept in mind because of the communal values and related problem ownership.

The layer approach helps to define for which issues a backcasting design method can work and for which a growth model. As the two following cases illustrate, a combination of both strategies seems most effective. Where system choices, such as water, infrastructure and energy networks ask for an approach of backcasting design, especially on the third and fourth layer a more adaptive approach is required.

We finish this article with two cases that illustrate how the design strategies of backcasting and growth model can work in practice. Furthermore, what the role of the layer approach and UDM plays in these approaches. We have chosen these cases because they are part of the developments on the largest scale for the coming years in the urban parts of the Randstad. Both are reclaimed land areas, which means that our thinking about the combination of new real estate development and investment in water systems, requires a strategic approach. They also both illustrate the tension between public and private interests and dealing with economic risks. Both cases are in the first development phase. UDM is used on an operational level in a process of knowledge co-production. In a 'knowledge co-production' [14], science and practice look for the best method for sustainable large area developments. How can these complex processes be shaped and steered? Co-production in this perspective should not be regarded as a fully fledged theory, but as an idiom; a way of interpreting and accounting for complex phenomena to avoid the strategic deletions and omissions of most of the other approaches in the social sciences [15]. In terms of sustainability, the key question in these cases is how concrete technical knowledge can, on an operational level, be integrated into the process of planning and design.

For the level of politics, more research is required. The four-year political cycle does not fit in with long-term sustainable investment at the network level. Long-term public-private investment programs can solve this problem. They create certainty at the layer of the networks and leave room for new insights and political debate at the layer of occupation. In democratic terms, this has implications for formal policy designs such as the Dutch structure vision. They should leave sufficient room for the political cycle and new insights on a smaller scale, for example on the amounts and types of housing. 
Another issue that needs more research is the type of organizations needed on the regional level, for example for larger geothermic or durable water systems.

\section{Co-Production in the Randstad: Two Cases}

In The World Cities (1966), Peter Hall compares the Randstad with monocentric metropoles like Paris, London and New York. The Randstad is polycentric with Amsterdam, Utrecht, The Hague and Rotterdam as major cities (third layer). Due to its polycentric nature and low city density, public transport networks are limited to railways and underground systems in Amsterdam and Rotterdam (second layer). The Randstad is a Delta Metropolis, with different reclaimed land areas and a so-called green heart that largely consists of peat (first layer). In terms of economic power, there is a clear distinction between the south and north part of the Randstad. Not only in terms of mainports (Schiphol in the north and the port of Rotterdam in the south), but also in terms of growth. In its recent policy document, Amsterdam positions itself as a metropolitan region. Part of the development of this region is due to the expansion of Almere by 60,000 dwellings. With exception of the 'Zuidplaspolder' (15,000 dwellings), in the south, we see many more small-scale developments. One of these smaller-scale developments is Rijswijk-Zuid, close to The Hague.

\subsection{North Wing, Case Almere Benoordenhout}

The national and local ambition for Almere is to have 350,000 inhabitants by 2030. This not only requires 60,000 new dwellings to be built, but also an improvement in the infrastructure. The ambition was defined before the economic crisis started, but policymakers were already aware of the fact that more than merely roads and buildings were needed to realize this ambition. Almere must become more attractive for different groups; this requires a strong identity. Almere also has high ambitions for sustainable development (C2C). It was obvious that both ambitions (growth and sustainability) have to be combined and support one another. The municipality organized various contests for the development of new large area developments. Almere Benoordenhout (Figure 1) is one of these.

According to the principles of UMD, the municipality of Almere worked out at government level a conceptual framework for this location and invited Dutch housing corporations to present their visions for Almere Benoordenhout. The corporations that participated were invited to work out their plans for the new area including (at least) 4,200 dwellings, 125,000 $\mathrm{m}^{2}$ surface area for offices, 20,000 $\mathrm{m}^{2}$ surface area for facilities (e.g., healthcare and schools), 500,000 $\mathrm{m}^{2}$ of surface area for businesses and $100,000 \mathrm{~m}^{2}$ of surface area for retail. Besides these programmatic requirements, the governmental framework also included high ambitions for sustainability (based on the principles of 'Cradle to Cradle') and economic requirements ('closed mass-haul diagram'). 
Figure 1. Location case Almere Benoordenhout.

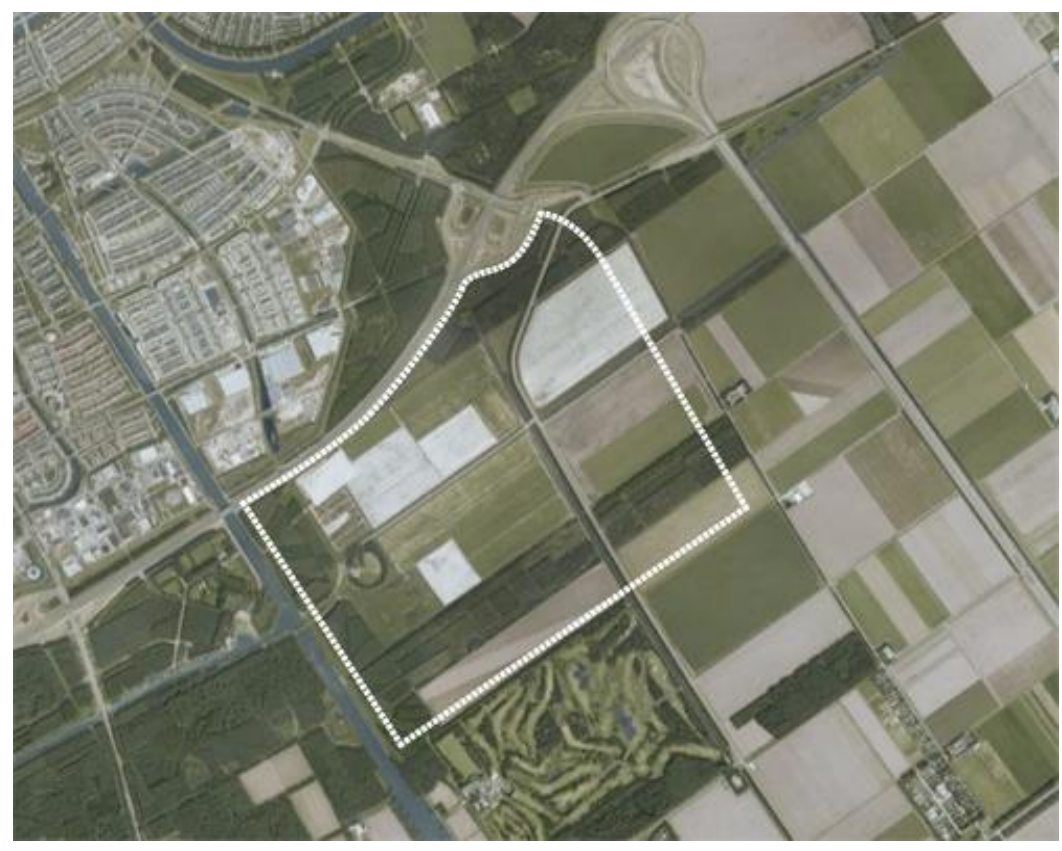

In this article, the approach by Vestia, one of the three housing corporations, is described. For Vestia this project was not only a competition but also a learning trajectory; acquiring process and content knowledge on sustainable area development. In line with UDM, the project was managed by a 'design manager'. Vestia also contributed with real estate and finance disciplines. Nyenrode Business University was asked to implement the more technical knowledge on sustainability. The central question at the start of the project was whether to define an ultimate goal (what does the area look like when it is finished? What steps are necessary to reach the ultimate goal?) or to define a set of goals for every new step, keeping in mind that it will take years to realize the project, knowing that, during these years, many unexpected external factors will occur. The team expected that the first approach, the 'backcasting model', would include many (economic) risks, whereas the second approach, the 'growth model' would offer a more flexible design for different possible futures (Figure 2). According to this consideration, the team of Vestia has chosen the 'growth model' for both, the second layer (infrastructure, water and energy supply) and the third layer (the occupation of the space by different functions such as living, working, recreation), thus concluding that high ambitions had to be met in every single step of the project. In the event the development of the project would stop (for a while or even altogether), the ambitions should be met anyway. After research by design, the project was divided into eight steps, each step consisting of a 'natural size' of 500-1,000 dwellings.

The option for the 'growth model' did have consequences for the choice of measures, which in this article is illustrated in the example of the energy concept. This decision was one of the main reasons why the team did not opt for a geothermic installation which is profitable for an area including at least 1,500-2,000 dwellings. According to the 'growth model' every step (including 500-1,000 dwellings) had to meet the ambition of a zero-energy area, which means that the amount of sustainable energy to be produced locally should at least be as much as is expected to be used. 
Figure 2. Design growth strategy for location Benoordenhout 'the strip' by Zandbelt van de Berg.

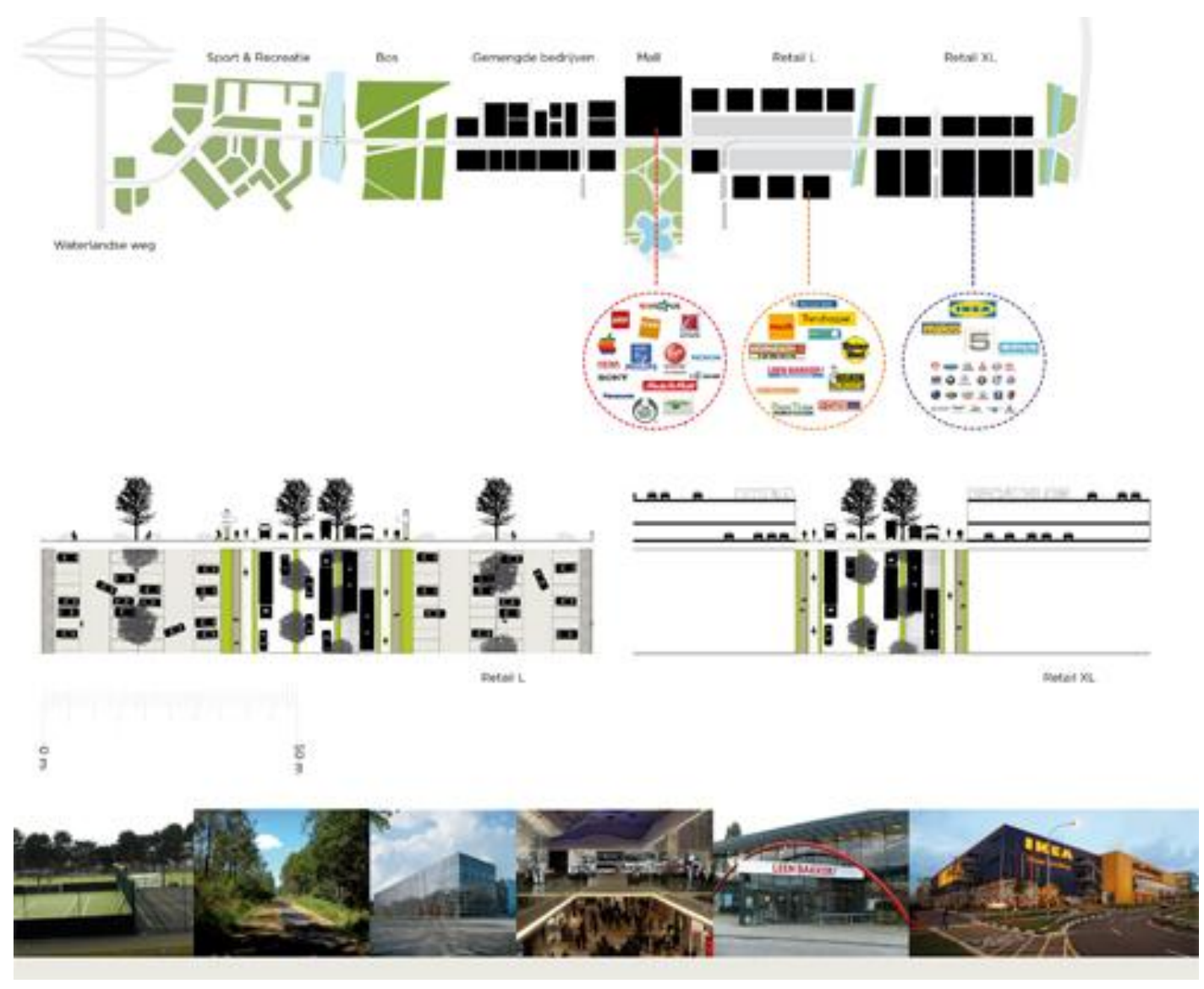

The starting point for the energy concept was the 'Trias Energetica', consisting of three steps to realize a $\mathrm{CO}_{2}$-neutral built environment. According to this strategy, first the energy demand of the buildings needs to be reduced by the construction and technical installation. Therefore priority was given to measures such as proper insulation, compactness, orientation, which offers the possibility to make use of passive solar energy in the winter, sun blinds and night-cooling for the summer, low-temperature heating and energy-saving ventilation systems.

Second, the remaining demand had to be covered by locally produced sustainable energy. So the third step in the 'Trias Energetica', making sparing use of fossil fuels, is not necessary. As the demand for heating and cooling could be reduced to a minimum level, the main challenge was not the production of sustainable thermal energy, but the production of sustainable electricity. Searching for a solution which is suitable for producing not only thermal energy but also electricity for as many as 500-1,000 dwellings, the team has chosen to use small local heat power plants in combination with photovoltaic cells. Biogas, produced on a farm close to the location, is used as fuel for the heat power plants. Thus the ambition of a zero-energy-area could be realized from the beginning of the project and the solution even offers an attractive business opportunity for the farmer. Already in the second step, biogas, produced by the local farm, is no longer sufficient. But heat power plants will still be used, which will use local organic waste as fuel - as far as necessary supplemented by other bio-fuels of the second or third generation (not fuels that are used for the production of food or have to be transported from a long distance). For any future steps, possibly new and better options will be available. 
Choosing small-scale solutions, according to the growth model, offers the possibility to repeat the choices or to make new choices when better options become available.

The photovoltaic cells are expected to be profitable in the future, but in the current situation they are not. As the Vestia team had to find solutions for the complete framework, including technical, social and economical sustainability, one of the following questions was how to compensate the higher costs and how new business opportunities could be created, involving the inhabitants of the new area. The answer was found in a combination: in order to compensate the higher costs from the very beginning, the team suggested installing windmills outside of the city. Due to their prominent visibility, the windmills were unattractive for the location itself, but they are profitable and can meet the demand for electricity for a large part of Almere, thus offering the possibility to earn money that can be invested in the photovoltaic cells on the site. In the future, everyone living and working in the area will be given the possibility to participate in the energy concept: by buying options they can become owners of the energy production. The involvement of the people who will live and work in the area is part of a participation model called 'Het Wijkschap'.

According to this model, the housing corporation, the municipality, developers, future users and inhabitants of the area all are involved in the development, realization and management of the project. Own initiatives of the users of the area are supported by the corporation in 'Het Wijkschap'. Several suggestions for possible initiatives that can support the creation of communal values have been worked out. The approach described for the energy concept is one of the suggestions, but according to the growth model 'Het Wijkschap' always offers the possibility to redefine the communal values in the future. In perspective of the layer approach, 'Het Wijkschap' can be seen as the fourth layer; the layer of the users.

This case illustrates that the design process focused not only on translating certain spatial questions. The process consisted of a continuous interaction and integration of input from different disciplines and scales, all with their own body of knowledge, interests and values. Not everything can be integrated; a prominent element such as energy can be an answer to this, as it provides focus in the process of negotiation. The main problem of the backcasting approach in terms of sustainable energy is the long-term investments. For a private organization such as Vestia, this means a (too) large financial risk. For this reason the focus in this case is on the growth model. Important merits of sustainable energy implementation:

- linking local energy production with energy use (example of biogas), by connecting different scales;

- introducing new technical solutions, without the immediate necessity of using them (photovoltaic cells); leaving space for incremental-decisions at a later stage.

\subsection{South Wing, Case Rijswijk-Zuid}

In the next 15 years, 4,000 dwellings will be realized in Rijswijk-Zuid (Figure 3) in combination with 15 hectares of working space and various services. The municipality of Rijswijk has the ambition to make this a sustainable development. Specific topics that will be addressed are: energy, water and greenery, and the direct involvement of future users in the development. The municipality has put 
together an external team consisting of a landscape designer, a financial expert and the Delft University of Technology for knowledge in the field of UDM and sustainability. For 10 months, this team worked on a Master Plan together with civil servants of Rijswijk.

Figure 3. Area case Rijswijk-Zuid.

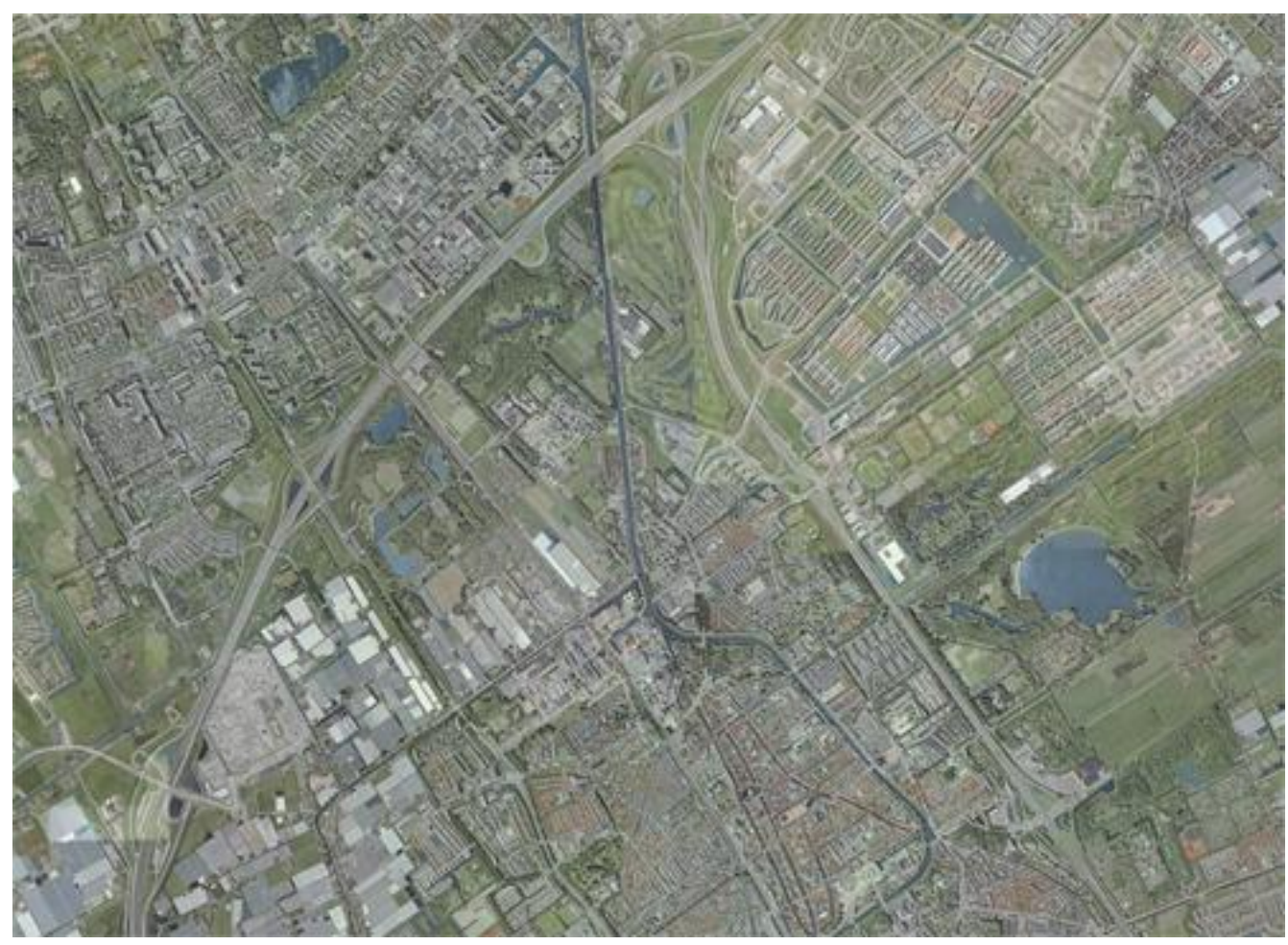

Design in this process was not only about the urban layout, but also about the process design. In this design the more strategic political level and the operational level were linked. At the operational level, different groups worked on programmatic, sustainable, and spatial questions. About every six weeks the knowledge was shared in a plenary meeting and integrated into an integral spatial concept. Also other stakeholders involved, such as the local water board, were invited to these meetings. Thus, UDM was used to merge the different interests of the actors involved where possible. The final result was used to make political decisions, ultimately resulting in a positive decision with respect to the Master Plan (Figures 4 and 5). This positive decision did not exclude politics. On the contrary, different elements of the plan were part of the political debate and require new research to be carried out. The most concrete example is the allotment gardens. The idea included in the design to integrate these with industrial development received a positive reaction at the operational level, but at the political level was widely rejected.

What was the method used at the operational level? SWOT and Scenario methods were used to investigate the important questions for this location. In the SWOT, strong (S) and weak (W) points were confronted with opportunities $(\mathrm{O})$ and threads $(\mathrm{T})$. With scenario methods, different possible future developments were investigated. The result of the SWOT was put into a matrix based on the layer approach. In combination with the MIRUP method and the outcomes of the scenario discussions, this information formed input for the final spatial concept. Green and water function as a framework for more flexible programmatic developments (Figure 6). Backcasting was used to define different 
possible ultimate ambitions. Examples are the development of a railway station, a collective energy system and choices regarding the water system. In an energy workshop with civil servants, the alderman responsible and experts from Delft University of Technology, different system choices were investigated. Starting point of the workshop was choosing a network. A network is necessary for balancing supply and demand. The conclusion was that an electricity network is necessary at the collective level, and that gas and/or heat delivery can be organized at the individual level. The result of this backcasting approach is a 'future design' that functions as a reference for decisions on a smaller scale. At this moment, different groups are working out the energy, infrastructure and water systems on smaller scales to allow more insight into possible choices and (long-term) investments. Part of this investigation will be the division of roles between public and private partners and the involvement of future users.

Figure 4. Result of negotiations on different levels for case Rijswijk-Zuid, image by Kuiper Compagnons.

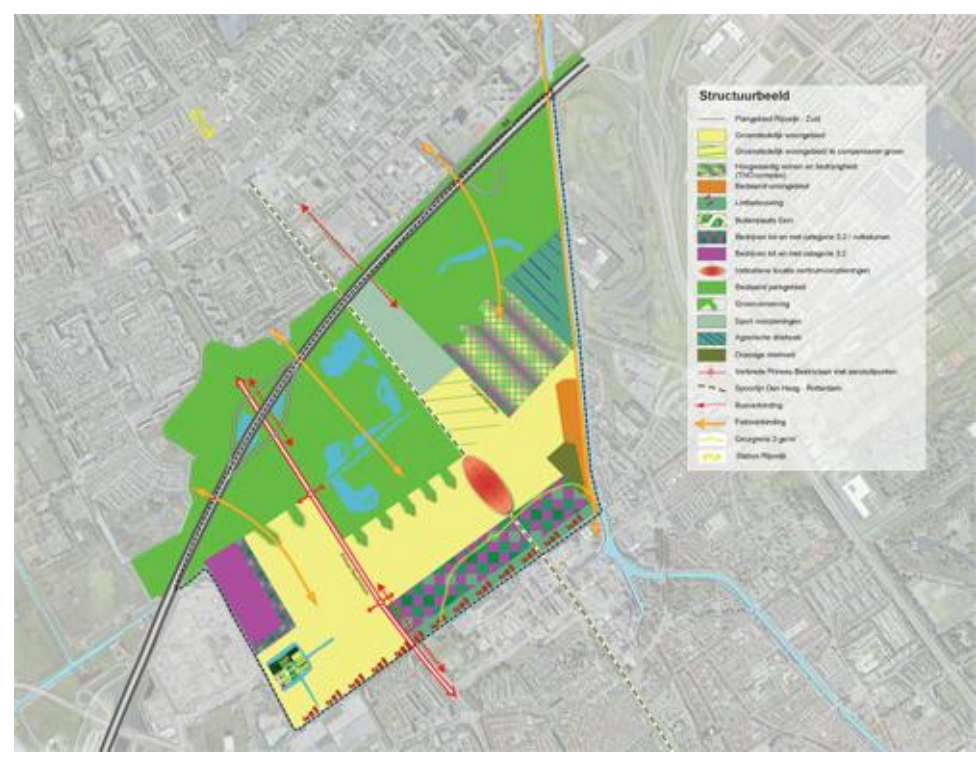

Figure 5. Additional ambitions for case Rijswijk-Zuid.

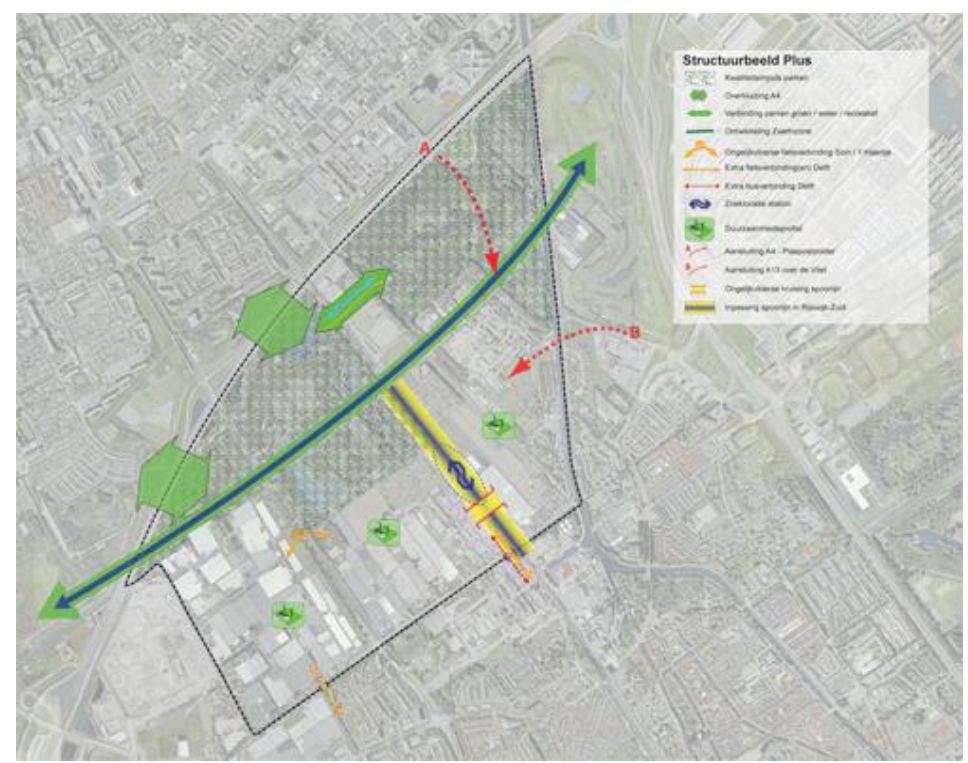


Figure 6. Spatial concept for Rijswijk-Zuid by Kuiper Compagnons.

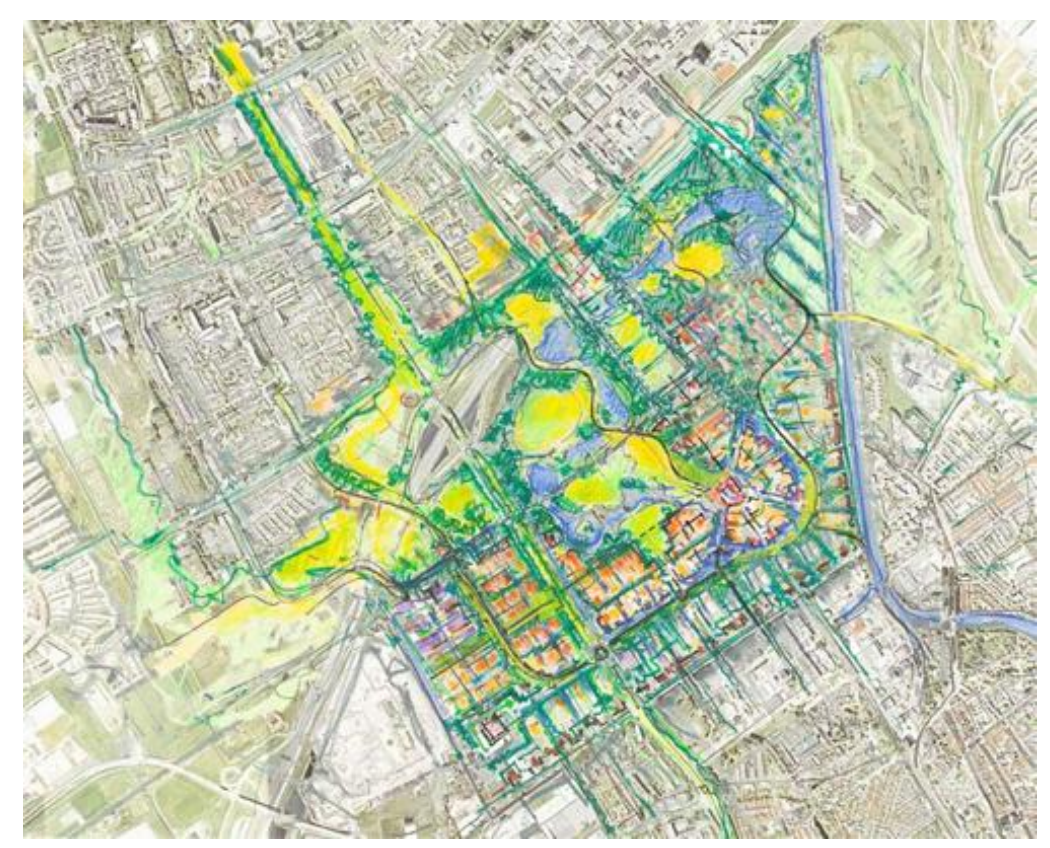

Through backcasting design at public sites, at the start of the development there will be, more than in the Almere case, clear insight into the public ambitions and the organization required to realize ambitions at a larger-scale level. Within this framework, for the whole area, a growth model design approach can be used by private developers and/or for the initiatives from citizens. Merits of this combination approach are:

- flexibility for public developments such as a railway station, by working with a conceptual framework instead of a blueprint, but also flexibility for smaller-scale solutions such as the 'future solution' of photovoltaic cells in combination with the windmill;

- clear insight into where the focus of public design should be; the second layer of the low dynamic water and green elements which can be integrated in public parks and other public spaces;

- clear boundary conditions for private parties.

And on the instrumental (design) level, it shows its merit for investigating the (dis)advantages of a collective or individual energy system.

\section{Conclusions}

The Dutch tradition in planning and urban design in the past decades has transformed from a public profession into a more public-private cooperation process. In countries such as the United Kingdom and the United States, there is a more strict division between planning and development. In the Netherlands there is a development attitude, both in private and public sites. In the past years, larger-scale developments showed a strong focus on creating global competitive environments. Looking at upcoming developments, questions of sustainability in terms of climate, energy and public 
transport will set the political agenda. The question addressed in this paper is how, in this context, design can help to incorporate sustainability into the (urban) area development at large.

Design in combination with knowledge co-production can help to obtain more insight into effective strategies. Theory and experience should be combined at different levels. As illustrated in this paper, the question of sustainability calls for interaction between the strategic and the project level. A backcasting and/or growth approach can be used as a supportive instrument. Both on public and/or private site UDM, based on the Mutual Gains approach, can be used as a tool for negotiation in this process both at the strategic and the operational project level. A first important merit of this approach is clear insight into public and private responsibilities. In the above cases, we have described how the layer approach in combination with backcasting can support public decisions at a larger-scale level. As the Almere case illustrates, larger-scale system choices deal with risks that commercial organizations may want to avoid within a more competitive setting. A clear governmental perspective, translated into a conceptual spatial framework including long-term investments, may help to solve this. Within this framework, at the occupational layer smaller-scale sustainable solutions can be chosen by public and/or private partners. A second merit is the flexibility both on the public and on the private side for future developments as illustrated by the example of photovoltaic cells in the Almere, and the railway station in the Rijswijk case.

A weak point can be too much focus on integration. A clear focus such as energy in the Almere case can help in the process of negotiation. Another weak point can be a closed process that leaves no room for new initiatives or political debate. A distinction between the network layer and the layer of occupation can help to allow room for political debate at the right level of the scale. Designers should be more aware of the different functions their designs can have. Not only at the level of politics, but also with regard to end users. Involvement of users calls for new design strategies. On a lower scale, an important question is what the contribution of users (businesses and citizens) can be in the realization and maintenance of energy, water and infrastructure networks. Finally, drawing on the knowledge from abroad, the introduction of more private law might help to stimulate this type of smaller-scale user initiatives. By 'designing the future' in terms of content, process and communication, we hope to bring these questions to an answer.

\section{References}

1. Zeeuw, W.C.T.F. De engel uit het marmer (The Angel of Marble), 4th ed.; Delft University of Technology: Delft, The Netherlands, 2007; p. 7.

2. Franzen, A.J.; Zeeuw, W.C.T.F. Urban area development towards room for entrepreneurship. Urban Plan. Int. 2009, 2, 30-33.

3. Needam, B. Een andere marktwerking (Different Market Competition); Nai Uitgevers/Ruimtelijke Planbureau: Rotterdam, The Netherlands, 2005.

4. Crimson Architectural Historians. Rotterdam. Story of an Open City (Movie); Architectural Biennale 2009: Rotterdam, The Netherlands, 2009.

5. Flyvbjerg, B. Making Social Science Matter: Why Social Inquiry Fails and How It Can Succeed Again; Cambridge University Press: Cambridge, UK, 2001. 
6. Koppenjan, J.; Klijn, E.H. Managing Uncertainties in Networks; Routledge: New York, NY, USA, 2004.

7. van Hal, A. Fusie van belangen, over duurzaamheid en rendement in de bouwsector (Merger of Interests; on Sustainability and Return in the Construction Sector); Nyenrode Business University: Breukelen, The Netherlands, 2009.

8. Swyngedouw, E. The Post-Political City. In Urban Politics Now, Re-Imaging Democracy in the Neoliberal City; NAi Publishers: Rotterdam, The Netherlands, 2007.

9. Goedman, A.; van der Burg, J. Multi-Level Strategic Planning in NL. In Proceedings of the 43rd ISOCARP Conference, Antwerp, Belgium, 19-23 September 2007.

10. Susskind, L.E.; Cruikchank, J.L. Breaking Robert's Rules; Oxford University Press: Oxford, UK, 2006.

11. Edelman, H. Urban Design Management; Publication of Architecture, Helsinki University of Technology: Helsinki, Finland, 2007; p. 21.

12. Rijke, J.; Zevenbergen, C.; Veerbeek, W. State of the Art Klimaat in de stad (Climate in the City); UNESCO-IHE: Delft, The Netherlands, 2009.

13. Ackoff, R.L.; Magidson, J.; Addisson, H.J. Idealized Design: Creating an Organization's Future; Wharton School Publishing: Philadelphia, PA, USA, 2006.

14. Regeer, B.J.; Bunders, J.F.G. KennisCoCreatie samenspel tussen wetenschap en praktijk (KnowledgeCoCreation: A Concerted Action between Science and Practice); VU Amsterdam for RMNO: Amsterdam, The Netherlands, 2007.

15. Jasanoff, S. States of Knowledge, the Co-Production of Science and Social Order; Routledge: New York, NY, USA, 2005; p. 3.

(C) 2010 by the authors; licensee Molecular Diversity Preservation International, Basel, Switzerland. This article is an open-access article distributed under the terms and conditions of the Creative Commons Attribution license (http://creativecommons.org/licenses/by/3.0/). 